\title{
The Effect of Shade Houses on the Insect Pests and Yield of Three Important Plant Crops in Puerto Rico: Pepper, Capsicum annuum (Solanaceae), Watermelon, Citrullus lanatus (Cucurbitaceae), and Cabbage, Brassica oleracea (Brassicaceae) ${ }^{1}$
}

\author{
Irma Cabrera ${ }^{2}$, Eric W. Harmsen ${ }^{3}$, and Alberto Vélez ${ }^{4}$
}

\begin{abstract}
Shade houses are structures commonly used to grow plants while shielding them from unfavorable meteorological conditions. Differences in the insect pests, growth, and yield were determined for pepper, Capsicum annuum Linnaeus (Solanaceae); cabbage, Brassica oleracea L. (Brassicaceae); and watermelon, Citrullus lanatus (Thunberg) Matsumura and Nakai (Cucurbitaceae) grown inside and outside shade houses during 2016 and 2017 at the Agricultural Experiment Station in Juana Díaz, Puerto Rico. Only in peppers were populations of Anthonomus eugenii Cano, 1894 (Coleoptera: Curculionidae) and Helicoverpa zea (Boddie, 1850) (Lepidoptera: Noctuidae) lower within the shade house as compared to plantings in open field (100\% and $98 \%$, respectively). In contrast, there were no significant differences in insect pest abundances or in yield between the shade house and open field plants in watermelon, $C$. lanatus. Cabbage plants did not develop their characteristic "head" in the shade house. Some implications of the observed differences in crop health and growth are discussed.
\end{abstract}

Key Words: shade houses, population dynamics of pestiferous insects, key pests, pepper, Capsicum annuum, watermelon, Citrullus lanatus, cabbage, Brassica oleracea, Anthonomus eugenii, Helicoverpa zea

Resumen: Las casas de sombra son estructuras comúnmente utilizadas para cultivar plantas mientras son protegidas de condiciones meteorológicas desfavorables. Se estudiaron los diferentes insectos plaga, el crecimiento y el rendimiento en el pimiento (variedad cubanelle), Capsicum annuum L. (Solanaceae); el repollo Brassica oleracea L. (Brassicaceae); y sandías, Citrullus lanatus (Thunberg) Matsumura yd Nakai (Cucurbitaceae) cultivadas dentro y fuera de las casas de sombra durante el 2016 y el 2017 en la Estación Experimental Agrícola de Juana Díaz, Puerto Rico. Solamente en el pimiento, las poblaciones de Anthonomus eugenii Cano, 1894 (Coleoptera: Curculionidae) y Helicoverpa zea (Boddie, 1850) (Lepidoptera: Noctuidae) disminuyeron dentro de la casa de sombra en comparación con las siembras en campo abierto ( $100 \%$ y $98 \%$, respectivamente). No hubo diferencias significativas en las poblaciones de insectos plagas y el rendimiento entre la casa de sombra y las plantas de campo abierto en sandías, Citrullus lanatus. Las plantas de repollo no desarrollaron su "cabeza" o roseta foliar

1 Submitted on September 29, 2019. Accepted on October 13, 2019. Last revisions received on October 13, 2019.

${ }^{2}$ Professor, Department of Agroenvironmental Sciences, University of Puerto Rico, Mayagüez Campus, Mayagüez 00682 Puerto Rico. E-mail: irma.cabreraasencio@upr.edu

${ }^{3}$ Professor, Department of Agricultural and Biosystems Engineering, University of Puerto Rico, Mayagüez Campus, Mayagüez 00682 Puerto Rico. E-mail: eric.harmsen@upr.edu

${ }^{4}$ Research Assistant, Agricultural Experiment Station, University of Puerto Rico, Mayagüez 00682 Puerto Rico. E-mail: albertovelez@gmail.com

DOI: 10.9784/LEB7(1)Cabrera.01

Electronically available on October 16, 2019. Mailed on October 16, 2019. 
característica dentro de las casas de sombra. Se discuten algunas implicaciones de las diferencias observadas en la salud y el crecimiento de los cultivos.

Palabras Claves: casas de sombra, dinámica poblacional de insectos plagas, plagas claves, pimiento, Capsicum annuum, col, Brassica oleracea, sandía, Citrullus lanatus, Anthonomus eugenii, Helicoverpa zea

\section{Introduction}

Background: The effective management of insect pests requires the evaluation of different control of methods. The use shade houses, or structures with a screen akin to giant mosquito nets to mechanically keep away arthropods and the diseases they transmit, are an alternative pest control (Figures 1 and 11). In Puerto Rico, the Department of Agriculture promotes investigations on the use of shade houses. Farmers evaluate these systems to test whether shade houses decrease pests and increase crop yields. Majumbar (2010) and Santoyo and Martínez (2012) reported the decrease of insect pest and diseases in shade houses. However, shade houses could affect photosynthesis in watermelons, because the photosynthetic rate decreased significantly when seedlings were grown under low light condition (Sun et al. 2009). Different colors in the netting could influence in the production and quality that increase total yield in peppers (Ilic et al. 2017). While López-Marín et al. (2011) said that some shade generated by this structure may be optimal to produce high-quality peppers.

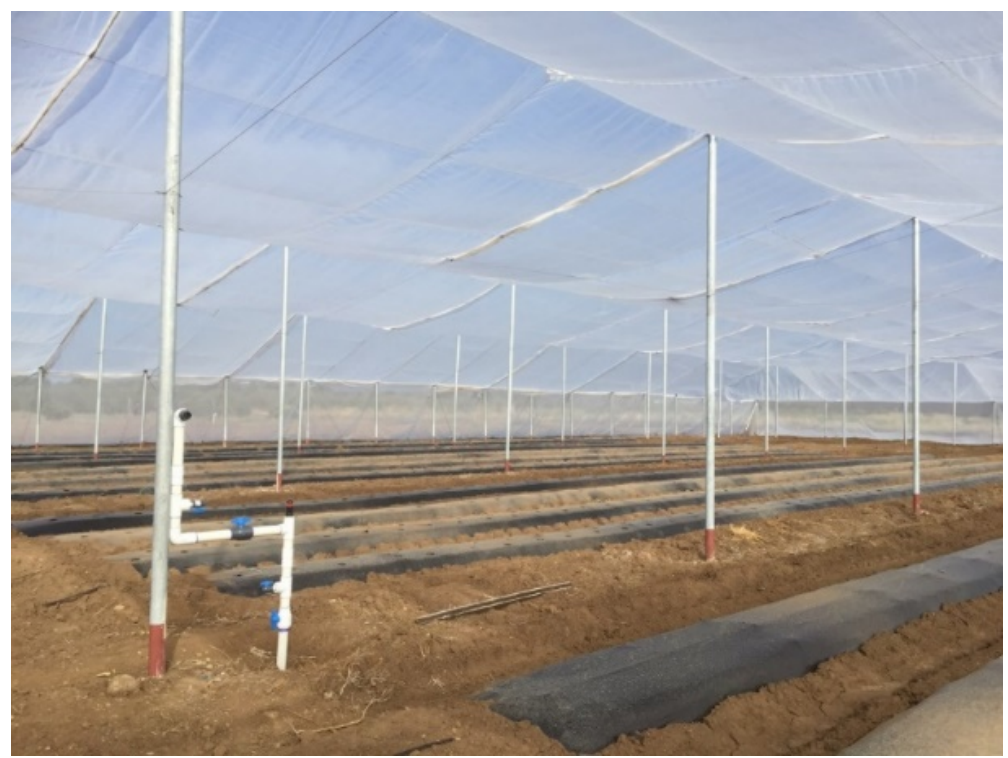

Figure 1. Interior view of shade house ready to be used for the experiments (see also Figure 11, p. 21). Note that this large structure is covered by material resembling mosquito netting. The control trials, namely plants grown out of shade houses, were conducted next to the shade houses. 
The Problem: Three important agricultural crops in Puerto Rico, peppers, Capsicum annuum Linnaeus (Solanaceae); cabbage, Brassica oleracea Linnaeus (Brassicaceae); and watermelons, Citrullus lanatus (Thunberg) Matsumura and Nakai (Cucurbitaceae) have experienced yield reductions since the 1990's. For example, although cabbage production in Puerto Rico during 2014-2016 remained at approximately $811,200 \mathrm{~kg}$, cabbage production surpassed 2,724,000 kg during the 1970s to 1980s (Census of Agriculture Puerto Rico 2007/2012). According to farmers with whom author IC have spoken, one of the causes of those reductions has been insect pests. Similar declines have been documented for peppers and watermelons. Consequently, farmers in the municipality of Santa Isabel, where a significant fraction of those cultivars are produced in Puerto Rico, have reduced seed sowing since 2009-2010 to avoid the loss of their capital investment (Agronomist Manuel Crespo, Land Authority of Puerto Rico, personal communication to author IC).

The Pests: The pepper weevil, Anthonomus eugenii Cano, 1894 (Coleoptera: Curculionidae) is a serious pest of peppers, Capsicum annuum Linnaeus (Solanaceae). Pepper production loses have reached more than $89 \%$ of fruit production in Puerto Rico (Abreu and Armstrong 2002). Segarra and Pantoja (1988) estimated that economic damage occurs at adult population densities of only 0.01 beetle per plant or one beetle per 100 plants. Farmers have difficulty establishing good management practices, such as cultural methods for the control of this weevil, mostly because implementation is expensive.

New diseases, such as the watermelon vein decline, transmitted by whiteflies (Hemiptera: Aleyrodidae, Baker et al. 2008) have exacerbated the insect pest problems already documented for watermelon, $C$. lanatus. The use of insecticides and silver mulch are being explored for management of whiteflies in watermelon, but other control practices need to be applied (Roberts et al. 2007).

The diamondback moth (Lepidoptera: Plutellidae), Plutella xylostella (Linnaeus, 1758), has been long being considered a significant pest of cabbage, Brassica oleracea Linnaeus (Brassicaceae) (Harcourt 1957, Capinera 2018). During 2010 the Land Authority of Puerto Rico reports that the number of larvae of P. xylostella increased 35\% (Crespo, personal communication to author IC). Consequently, farmers in Santa Isabel, Puerto Rico reduced sowing during the years 2009-2010 (2016, Crespo, personal communication to author IC). The increased damage from different pests in peppers and watermelon was as severe as those reported for cabbage (2016 Crespo, personal communication to author IC).

A testable hypothesis: Effective insect pest management requires the scientific evaluation of control measures. The use of physical control barriers, such as shades houses, structures commonly used to grow plants while shielding them from unfavourable meteorological conditions, is an alternative to traditional insecticide treatments and other forms of control. In many parts of the world, insect nets or screens, are commonly used to keep away insects and the diseases 
they transmit. Majumdar (2010) have documented the successful use of net houses to control numerous insect pests in Alabama, USA. In México, the use of shades houses was effective to reduce pests in crops. Santoyo Juárez and Martínez Alvarado (2012) reported that when they planted habanero peppers in shade houses, there was a 50\% decrease in insecticide and fungicide applications.

\section{Study Site}

\section{Methods}

The study was conducted in the Fortuna Experiment Station near Juana Díaz, Puerto Rico (18.025995 north, -west $66.526818^{\circ}$ west), 21 meters above mean sea level, and approximately $5 \mathrm{~km}$ from Puerto Rico's southern coast. Prevailing winds are from the east, varying from varying from northwest to southeast to SE, with maximum wind speeds of $5.5 \mathrm{~m} / \mathrm{s}$ from the southeast (Wegley et al. 1981). Table 1 shows the long-term average monthly maximum, minimum, average air temperatures and rainfall for the study site (Albright 2010). The warmest month was August with an average maximum temperature $33.2^{\circ} \mathrm{C}$. The months with the minimum and maximum rainfall are January and September with $23.1 \mathrm{~mm}$ and $161.8 \mathrm{~mm}$, respectively. The total annual rainfall is $977.1 \mathrm{~mm}$. The region is semiarid (Harmsen et al. 2014).

\section{Objectives}

This project had three objectives. First, to determine the effects of the shade houses in the control of Anthonomus eugenii and Helicoverpa zea on pepper, Bemisia spp. on watermelon, and Plutella xylostella on cabbage. Second, to quantify the yield of all those crops in and out of shade-house conditions. Third, to compare the meteorological conditions, such as temperature, relative humidity, and solar radiation (or irradiance) inside and outside the shade houses.

\section{Microweather}

To evaluate the differences in microweather caused by the shade houses, a new, factory-calibrated Davis weather station (GroWeather Vantage Pro 2, https://davisinstruments.com) was installed inside the shade house and compared with a nearby weather station outside of the shade house. The outside weather station was installed in 2006 and it is part of and maintained by the United States Department of Agriculture (USDA) Natural Resource Conservation Service (NRCS) Soil Climate Analysis Network (SCAN) (https://www.wcc.nrcs.usda.gov/scan/). Data from the Davis station were available every 15 minutes on the Internet; data captured by the NRCS SCAN station data is available hourly Weather parameters of interest in this study included air temperature, relative humidity, wind speed, and solar radiation. 
Experiments with pepper, watermelons, and cabbage

Experiments were conducted during the spring (December 2016 to May 2017) and autumn (September 2017 to December 2017) production seasons. During 2016, we grew pepper (hybrid Key West, a type of variety cubanelle Capsicum annum), and cabbage (hybrid Blue Vantage, B. oleracea). During the 2017 season, we grew pepper (hybrid Key Largo, another type of cubanelle, and watermelon (hybrid Royal Sweet), C. lanatus. The variables measured were the number of insects present, quantity of insect damage per plant, and commercial yield per plant species.

Table 1. Monthly average maximum, minimum air temperatures and rainfall for the Fortuna Experiment Station near Juana Díaz, Puerto Rico (Albright 2010, see also Goyal and González. 1989).

\begin{tabular}{|c|c|c|c|c|}
\hline Month & $\begin{array}{c}\text { Minimum } \\
\text { Temperature, } \\
{ }^{\circ} \mathbf{C}\end{array}$ & $\begin{array}{c}\text { Maximum } \\
\text { Temperature, } \\
{ }^{\circ} \mathbf{C}\end{array}$ & $\begin{array}{c}\text { Average } \\
\text { Temperature, } \\
{ }^{\circ} \mathbf{C}\end{array}$ & $\begin{array}{c}\text { Rainfall, } \\
\mathbf{m m}\end{array}$ \\
\hline January & 19.4 & 30.6 & 24.1 & 23.1 \\
\hline February & 19.4 & 30.6 & 24.2 & 32.3 \\
\hline March & 19.4 & 30.6 & 24.6 & 46.5 \\
\hline April & 20.6 & 31.1 & 25.2 & 64.3 \\
\hline May & 22.2 & 31.7 & 26.2 & 117.9 \\
\hline June & 23.3 & 32.2 & 27.1 & 59.2 \\
\hline July & 23.3 & 32.8 & 27.4 & 66.5 \\
\hline August & 22.8 & 33.3 & 27.3 & 105.7 \\
\hline September & 22.2 & 32.8 & 26.9 & 161.8 \\
\hline October & 21.7 & 32.2 & 26.7 & 154.9 \\
\hline November & 20.0 & 31.7 & 25.6 & 109.7 \\
\hline December & 23.1 & 31.1 & 24.5 & 35.3 \\
\hline $\begin{array}{c}\text { Annual average } \\
\text { (last cell, total) }\end{array}$ & 21.5 & 31.7 & 25.8 & 977.1 \\
\hline
\end{tabular}

Experiments were conducted in shade houses (dimensions, approximately $108 \mathrm{~m}$ long $\times 50 \mathrm{~m}$ wide $\times 20 \mathrm{~m}$ high) and in the nearby open field (Figures 2, 5, and 6). All agronomic and horticultural practices (e.g., soil preparation, 
insecticides applied, etc.) explained in the technological packages prepared by the Agricultural Experiment Station were used in these experiments in the shade houses as well as outside shade houses (Abrams et al. 1976, Martínez and Fornaris 2005, as well as Martínez and Fornaris 2015).

Year 1. Pepper. A complete randomized experimental design trial consisting of four plots (3.66 m x $48.16 \mathrm{~m}$ per plot) per experiment inside the shade house (experimental group) and four plots per experiment outside the shade house (control group) were used. We evaluated ten plants per plot for a total of 40 plants per group for a total of 80 evaluated plants per week. During December 2016 to May 2017, once per week, we evaluated populations of adult $A$. eugenii, adult $H$. $z e a$, and other arthropods, such as thrips (Thysanoptera), whitefly (Hemiptera: Aleyrodidae), mites (Acari), and several species of Spodoptera (Lepidoptera: Noctuidae) from each of ten pepper plants per plot.

Cabbage. The larvae of $P$. xylostella and other insects were counted in ten plants per plot, as the experiments with peppers. For all experiments on year 1, the yield was assessed by harvesting all marketable fruit from twenty randomly selected plants per plot, 80 plants on the control group and 80 in the experimental group). Fruits were weighted and graded for quality (Figure 6, Table 6).

Year 2. During the second year, watermelon and pepper were planted. Randomized experiments were conducted in shade houses and in the open field, nearby. During year 2, we planted peppers and watermelons. The same procedures and practices for plant and insect evaluations and yield were used during this time. For all experiments, the incidence of whitefly nymphs was counted once per week. Counts were done on five randomly selected plants from one row per plot. Yields were assessed by harvesting all marketable fruits from twenty plants per plot. Fruits were weighed and graded for quality. Other important pests, such as leaf-miners, thrips, aphids, lepidopterans, and mites were also evaluated.

\section{Statistical Analyses}

All data was evaluated for normality using a modified Shapiro-Wilks test. Insect population sizes using scales created by author IC were transformed to reduce correlations between means and variances using the non-parametric Kruskal-Wallis test. Yield data was studied with Analysis of Variance. Those tests are available in InfoStat (Di Rienzo et al. 2018).

\section{Results and Discussion}

Shade houses support the cultivation of peppers (Figure 2) and watermelons (Figure 5). Pepper plants grown within shade houses harbored very low populations of its main pests, A. eugenii and H. zea (Figure 3) corresponding with an increased yield. In Alabama (USA), shade houses benefit crops, such as tomato, Solanum lycopersicum Linnaeus (Solanaceae) and bell peppers as they exclude 82 to $100 \%$ of $H$. zea and Spodoptera exigua (Hübner, 1808) (Lepidoptera: Noctuidae) (Majumdar and Powell 2011). However, in Asia it was 
demonstrated the net houses are less effective reducing pest in vegetable when rain and wind are a strong presence (Talekar et al. 2003).
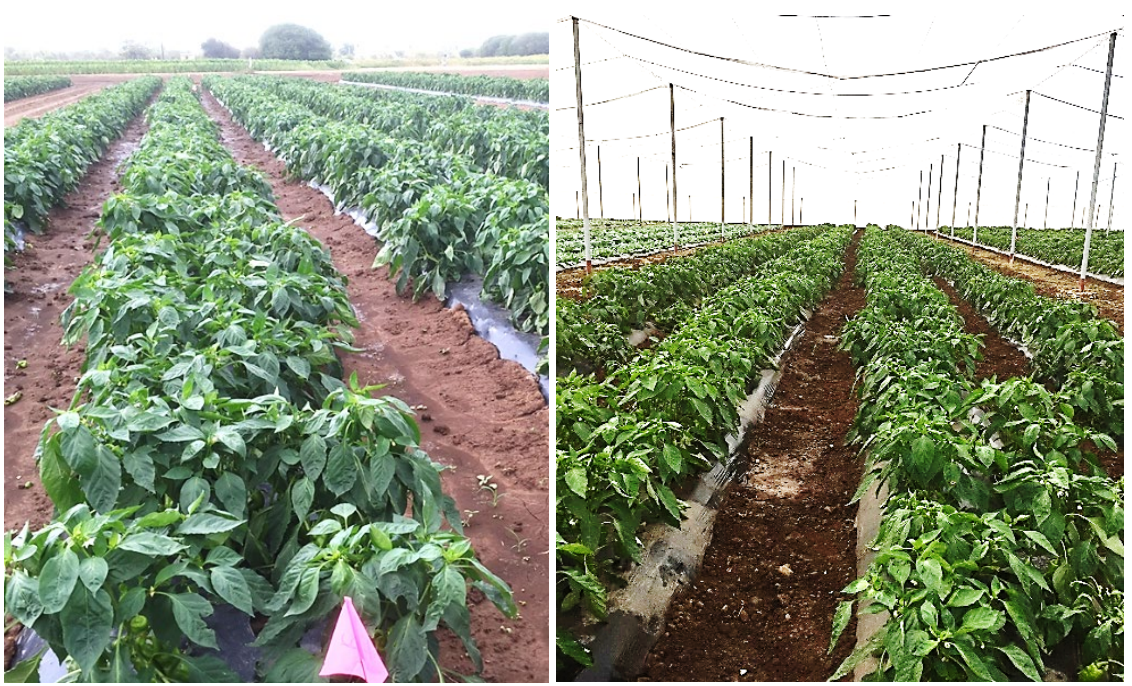

Figure 2. Pepper plants grown inside grown in the field (left panel) and inside a shade house (right panel).

Only in cubanelle peppers were there differences between the shade house and open field experiments. The populations of A. eugenii and $H$. zea (Figure 4) in open field increased in the sixth week after the beginning of the growing experiments. Such increases were not observed in shade houses. The reduction in the population of A. eugenii and H. zea in the shade house was $100 \%$ and $98 \%$ respectively (Table 2). This reduction in $H$. zea was reported by Madjudar and Powell (2011) for bell peppers. However, the incidence of whiteflies and mites was always very high when compared with plantings outside the structure (Figure 4). Thrips and mites could get through the pores (estimated pore diameter $0.3 \mathrm{~mm}$ ) in the fabric of the shade house. The best pepper yield was achieved in shade house conditions (Table 3). 

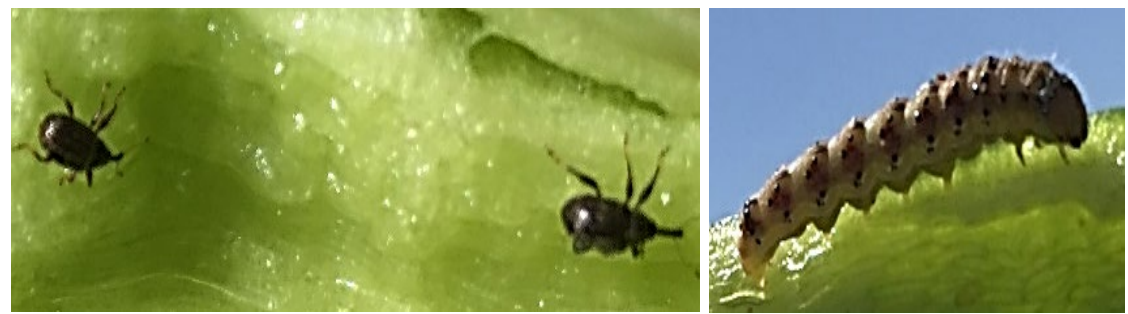

Figure 3. Insect pest of peppers. Anthonomus eugenii weevils (approximately $3 \mathrm{~mm}$ long) on pepper (left panel) and Helicoverpa zea larva (approximately $40 \mathrm{~mm}$ long).

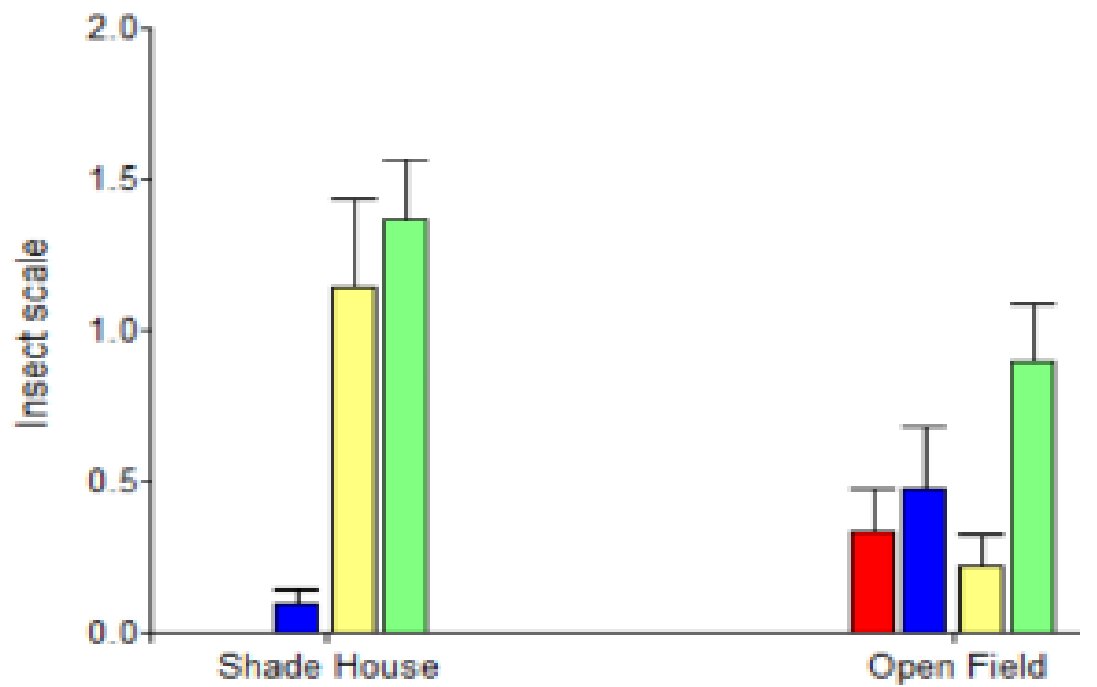

Figure 4. Population means for some arthropods in pepper. Anthonomus eugenii, Helicoverpa zea, Bemisia sp., and mites for the experiments in shade houses and in open field. Red represents adult $A$. eugenii; blue, larval $H$. zea, yellow, mites; and green whiteflies adults. Lines represent standard error. Insect scale: 1 represents 1 to 3 insect per leaf, 2 represents 4 to 6 insects per leaf, 3 represents 7 to 10 insects per leaf, 4 represents 11 to more insect per leaf populations of Anthonomus eugenii, Helicoverpa zea, Bemisia sp., and mites. 
Table 2. Reduction in number of Anthonomus eugenii and Helicoverpa zea inside the shade house and compare with open field in cubanelle crops.

\begin{tabular}{|c|c|c|c|c|}
\hline $\begin{array}{l}\text { Cubanelle } \\
\text { Pepper } \\
\text { Sowing }{ }^{1}\end{array}$ & $\begin{array}{c}\text { Anthonomus } \\
\text { eugenii } \\
\text { Shade House }\end{array}$ & $\begin{array}{c}\text { Anthonomus } \\
\text { eugenii } \\
\text { Open Field }\end{array}$ & $\begin{array}{c}\text { Helicoverpa } \\
\text { zea } \\
\text { Shade House }\end{array}$ & $\begin{array}{c}\text { Helicoverpa } \\
\text { zea } \\
\text { Open House }\end{array}$ \\
\hline 1 & 0 & 4.25 & 1 & 9.25 \\
\hline 2 & 0 & 3.75 & 0 & 2.25 \\
\hline 3 & 0 & 0 & 0.25 & 2.25 \\
\hline mean & 0 & 2.32 & 0.42 & 4.58 \\
\hline$\pm \mathrm{sd}$ & 0 & \pm 2.67 & \pm 0.52 & \pm 4.04 \\
\hline $\begin{array}{c}\text { Insect } \\
\text { exclusion } \\
\text { efficiency } \\
(\%)^{2}\end{array}$ & \multicolumn{2}{|c|}{$100 \%$} & \multicolumn{2}{|c|}{$98 \%$} \\
\hline ANOVA $^{3}$ & \multicolumn{2}{|c|}{$\begin{array}{c}\mathrm{F}=5.91 \\
\mathrm{p}=0.019^{*}\end{array}$} & \multicolumn{2}{|c|}{$\begin{array}{c}\mathrm{F}=6.92 \\
\mathrm{p}=0.012^{*}\end{array}$} \\
\hline
\end{tabular}

${ }^{1}$ Insect count is accumulative for eight weeks for each sowing. Scale count indicates population density and activity during the sowing.

${ }^{2}$ Insect exclusion efficiency is the percentage reduction in pest numbers inside the Shade House compared to open field.

${ }^{3}$ Analysis of variance, available in InfoStat (Di Rienzo et al. 2018).

Table 3. Yield of cubanelle pepper in and out the shade house.

\begin{tabular}{|c|c|c|c|c|}
\hline $\begin{array}{c}\text { Shade } \\
\text { House }\end{array}$ & $\begin{array}{c}\text { Total of } \\
\text { commercial, } \\
\text { fruits/hectare }\end{array}$ & $\begin{array}{c}\text { Total of non- } \\
\text { commercial, } \\
\text { fruits/hectare }\end{array}$ & $\begin{array}{c}\text { Commercial } \\
\text { weight, } \\
\mathrm{kg} / \mathrm{hectare}\end{array}$ & $\begin{array}{c}\text { Non- } \\
\text { commercial } \\
\text { weight, } \\
\mathrm{kg} / \mathrm{hectare}\end{array}$ \\
\hline In & $28,094^{\mathrm{a}^{*}}$ & $7,821^{\mathrm{b}}$ & $19,920.89^{\mathrm{a}}$ & $4,099^{\mathrm{a}}$ \\
\hline Out & $743^{\mathrm{b}}$ & $15,889^{\mathrm{a}}$ & $588.11^{\mathrm{b}}$ & $3,665^{\mathrm{a}}$ \\
\hline
\end{tabular}

* Columns with the same letter are not significantly different $(\mathrm{p}=0.05)$. Tukey test is available in InfoStat (Di Rienzo et al. 2018). 
Table 4. Average temperature, $\mathrm{RH}$, wind speed and solar radiation inside and outside of the shade house 2016 and 2017.

\begin{tabular}{|c|c|c|c|c|}
\hline & $\begin{array}{c}\text { Temperature, } \\
\text { oC }\end{array}$ & $\begin{array}{c}\text { Relative } \\
\text { Humidity } \\
(\%)\end{array}$ & $\begin{array}{c}\text { Wind } \\
\text { Speed* } \\
(\mathrm{m} / \mathrm{s})\end{array}$ & $\begin{array}{c}\text { Solar } \\
\text { Radiation } \\
\left(\text { Watts/m }{ }^{2}\right)\end{array}$ \\
\hline Inside & 27.05 & 76.48 & 0.36 & 198.26 \\
\hline Outside & 26.53 & 73.97 & 1.76 & 241.92 \\
\hline Inside - Outside & 0.53 & 2.52 & -1.40 & -43.66 \\
\hline Inside & 26.20 & 73.31 & 0.42 & 166.54 \\
\hline Outside & 25.23 & 72.24 & 1.90 & 221.84 \\
\hline Inside - Outside & +0.97 & +1.07 & -1.47 & -55.30 \\
\hline
\end{tabular}

*NRCS SCAN station wind speeds were adjusted to $2 \mathrm{~m}$ height using the method presented by Allen et al. (1998).

In watermelons (Figure 5), the insects evaluated remained in low numbers through the experiment. Likewise, the amount of commercial fruit and yield obtained was similar and no had significant differences inside and outside.
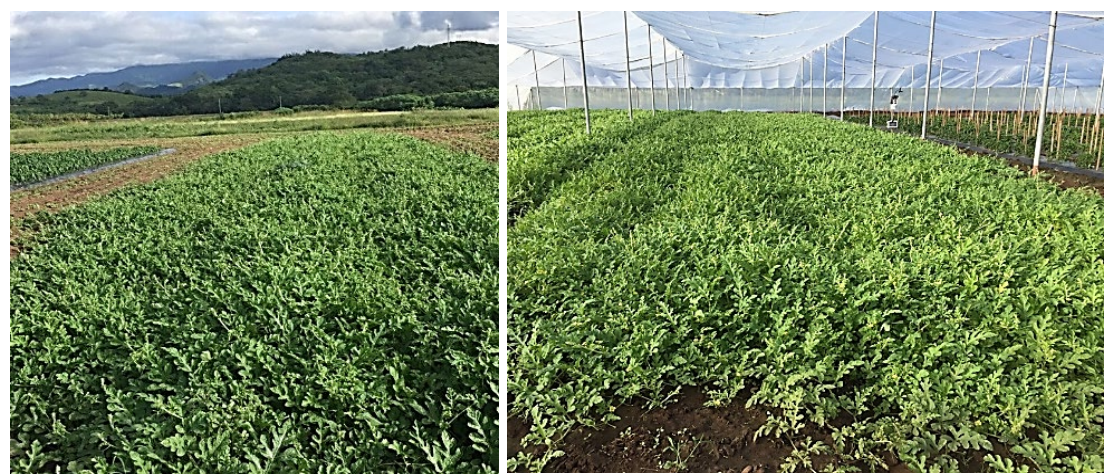

Figure 5. Watermelons grown in the open field (left panel) and inside a shade house (right panel). 
Table 5. Yield of watermelons in and out the shade house.

\begin{tabular}{|c|c|c|c|c|}
\hline $\begin{array}{c}\text { Shade } \\
\text { House }\end{array}$ & $\begin{array}{c}\text { Total of } \\
\text { commercial, } \\
\text { fruits/acre }\end{array}$ & $\begin{array}{c}\text { Total of non- } \\
\text { commercial, } \\
\text { fruits/hectare }\end{array}$ & $\begin{array}{c}\text { Commercial } \\
\text { weight, } \\
\mathrm{kg} / \text { hectare }\end{array}$ & $\begin{array}{c}\text { Non-commercial } \\
\text { weight, } \\
\mathrm{kg} / \text { hectare }\end{array}$ \\
\hline In & $1,942^{\mathrm{a}}$ & $308 \mathrm{a}$ & $102,951^{\mathrm{a}}$ & $7,005^{\mathrm{a}}$ \\
\hline Out & $2,042^{\mathrm{a}}$ & $63^{\mathrm{b}}$ & $104,827^{\mathrm{a}}$ & $3,539^{\mathrm{b}}$ \\
\hline
\end{tabular}

* Columns with the same letter are not significantly different $(\mathrm{p}=0.05)$. Tukey test is available in InfoStat (Di Rienzo et al. 2018).

In contrast, cabbage could not develop properly in the shade house as the foliage grew deformed or remained small (Figure 6). Cabbage plants grown outside experienced better plant development and had a higher yield. There were no differences in the arthropod pests between the plants grown in the shade house vs. cabbage grown outside the shade house.
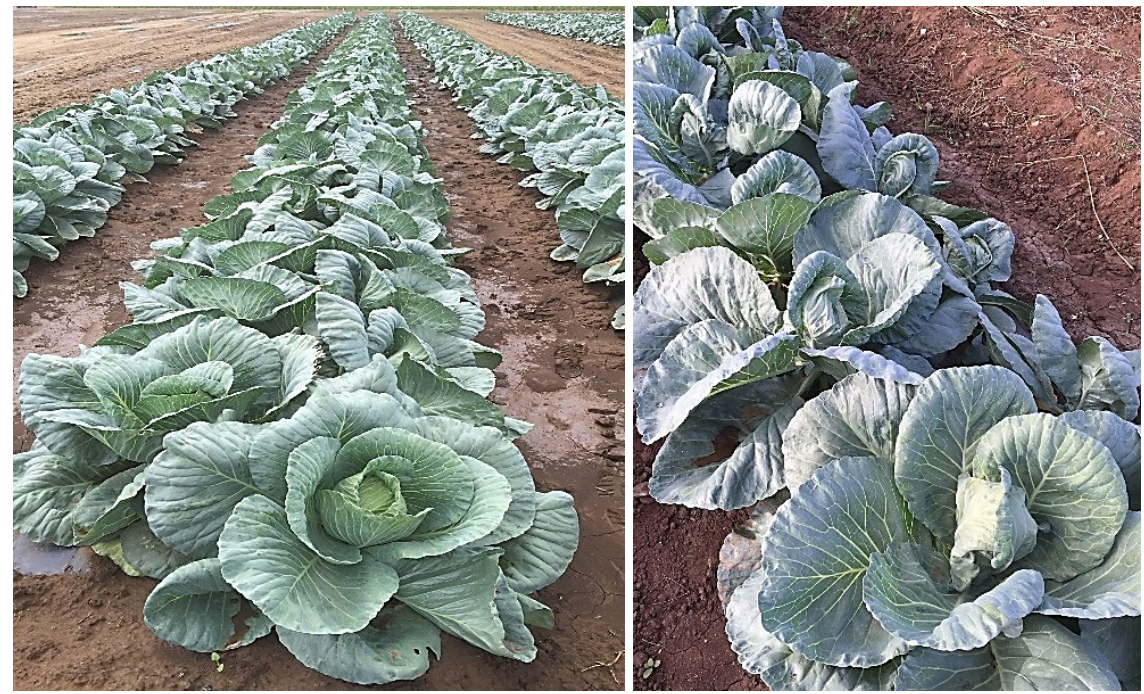

Figure 6. Cabbage grown in the open field (left panel), and inside a shade house (right panel). Note lack of well-defined "heads" on the cabbage plants grown inside shade houses. 
Table 6. Yield of cabbage in and out the shade house.

\begin{tabular}{|c|c|c|c|c|}
\hline $\begin{array}{c}\text { Shade } \\
\text { House }\end{array}$ & $\begin{array}{c}\text { Total } \\
\text { commercial, } \\
\text { fruits/hectare }\end{array}$ & $\begin{array}{c}\text { Total non- } \\
\text { commercial, } \\
\text { fruits/hectare }\end{array}$ & $\begin{array}{c}\text { Commercial } \\
\text { weight } \\
\mathrm{kg} / \text { hectare }\end{array}$ & $\begin{array}{c}\text { Non-commercial } \\
\text { weight, } \\
\mathrm{kg} / \text { hectare }\end{array}$ \\
\hline In & $1,464^{\mathrm{a}}$ & $1,655^{\mathrm{a}}$ & $12,553^{\mathrm{a}}$ & $15,832^{\mathrm{a}}$ \\
\hline Out & $3,296^{\mathrm{b}}$ & $1,197^{\mathrm{b}}$ & $39,567^{\mathrm{b}}$ & $13,383^{\mathrm{a}}$ \\
\hline
\end{tabular}

* Columns with the same letter are not significantly different $(\mathrm{p}=0.05)$. Tukey test is available in InfoStat (Di Rienzo et al. 2018).

\section{The microweather}

Air temperature, relative humidity, wind speed, and solar radiation were measured inside and outside the shade house from 18 March to 10 June 2016 and from 21 February to 2 May 2017. Table 4 shows a comparison of the average measured weather parameters. During 2016, measured differences between inside and outside (inside minus outside) air temperature, relative humidity, wind speed and solar radiation were $0.53{ }^{\circ} \mathrm{C}, 2.52 \%,-1.4 \mathrm{~m} / \mathrm{s}$ and $-43.66 \mathrm{Watts} / \mathrm{m}^{2}$, respectively, and $0.97^{\circ} \mathrm{C}, 1.07 \%,-1.47 \mathrm{~m} / \mathrm{s}$ and $-55.30 \mathrm{Watts} / \mathrm{m}^{2}$, respectively, during 2017. Figures 7 - 10 show the comparisons of air temperature, relative humidity, wind speed, and solar radiation, respectively, from 18 March to 10 June 2016. Differences in wind speed (Figure 9) and solar radiation (Figure 10) are the most striking.

The lower wind speed inside the shade house would have resulted in a lower leaf evapotranspiration rate. The average increase in air temperature of $0.75^{\circ} \mathrm{C}$, may have caused some heat stress to the plants grown inside the shade houses. Rice (Oryza sativa Linnaeus, Poaceae), corn (Zea mays Linnaeus, Poaceae), and many other plants show signs of stress when exposed to extreme heat (Bita and Gerats 2013). Although shade houses are assumed to reduce stress from insect herbivory, yields may have been higher if wind speeds were higher and consequently, air temperature lower. The average increase in relative humidity inside the shade house of $1.8 \%$ may also have contributed to a lower transpiration rate. The average difference between solar radiation inside and outside the shade house was 49.5 Watts $/ \mathrm{m}^{2}$. This reduction may have resulted in lower growth as a result of a lower photosynthetic rate. The lower solar radiation inside the shade house would have resulted in a lower net radiation load on the plant leaves, thus reducing leaf temperatures and heat stress, and therefore, would have tended to cancel out the negative effect of lower wind speeds. This lower solar radiation perhaps promoted a higher commercial yield in the shade house as it did for López-Marin et al. (2011). 


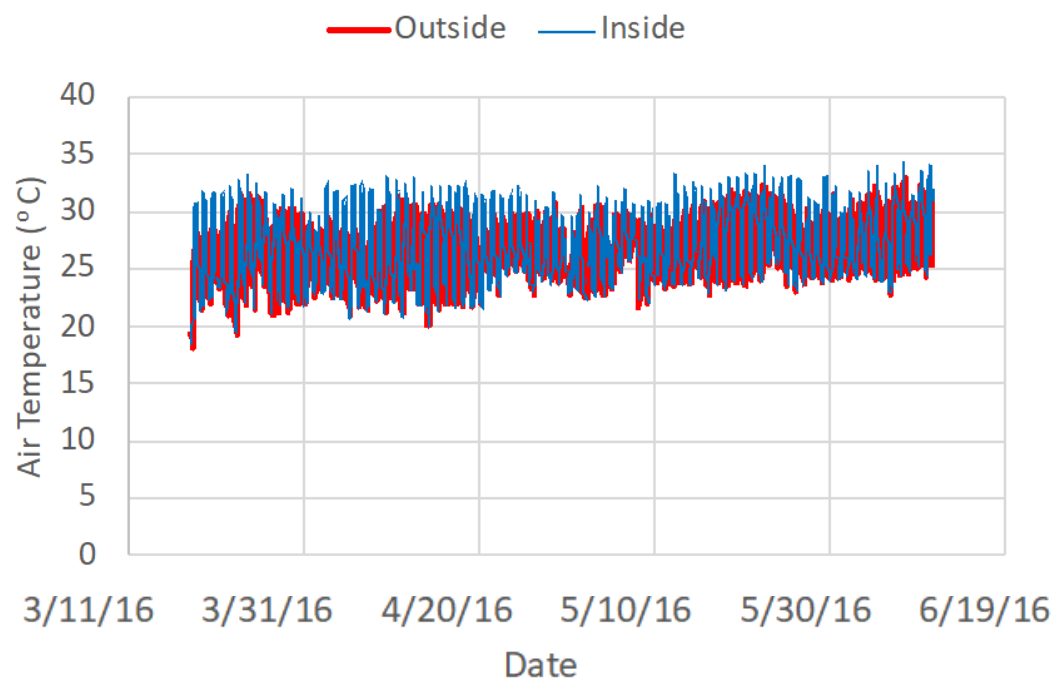

Figure 7. Comparison of air temperature inside and outside of the shade house between March 18 and June 19, 2016.

— Outside _ Inside

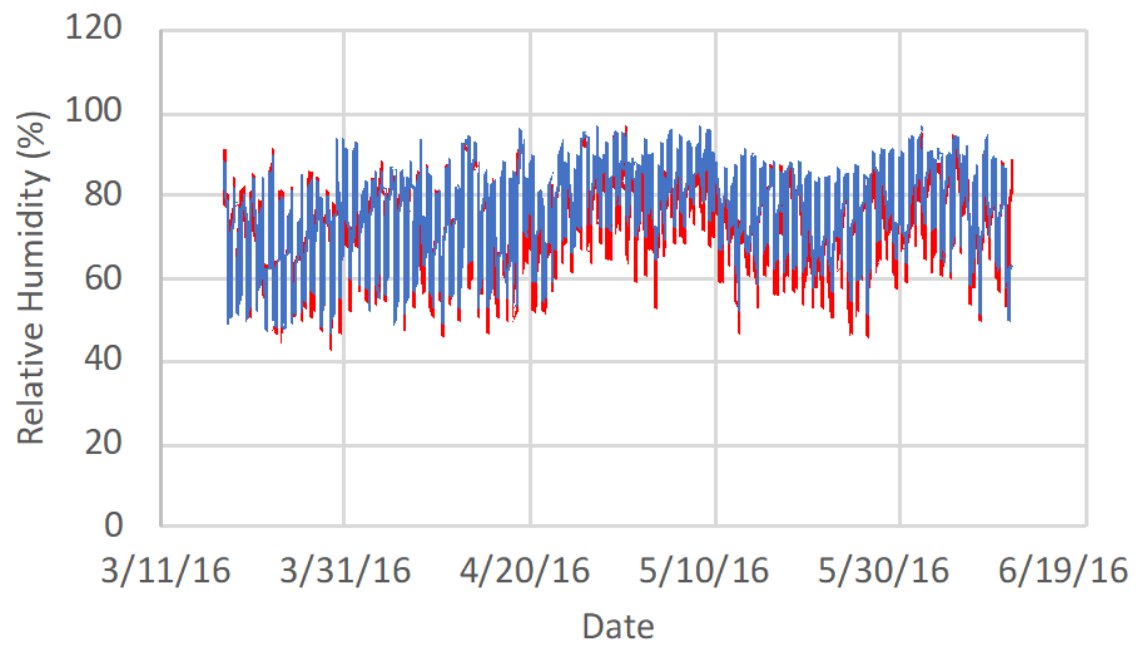

Figure 8. Comparison of relative humidity inside and outside of the shade house between March 18 and June 19, 2016. 


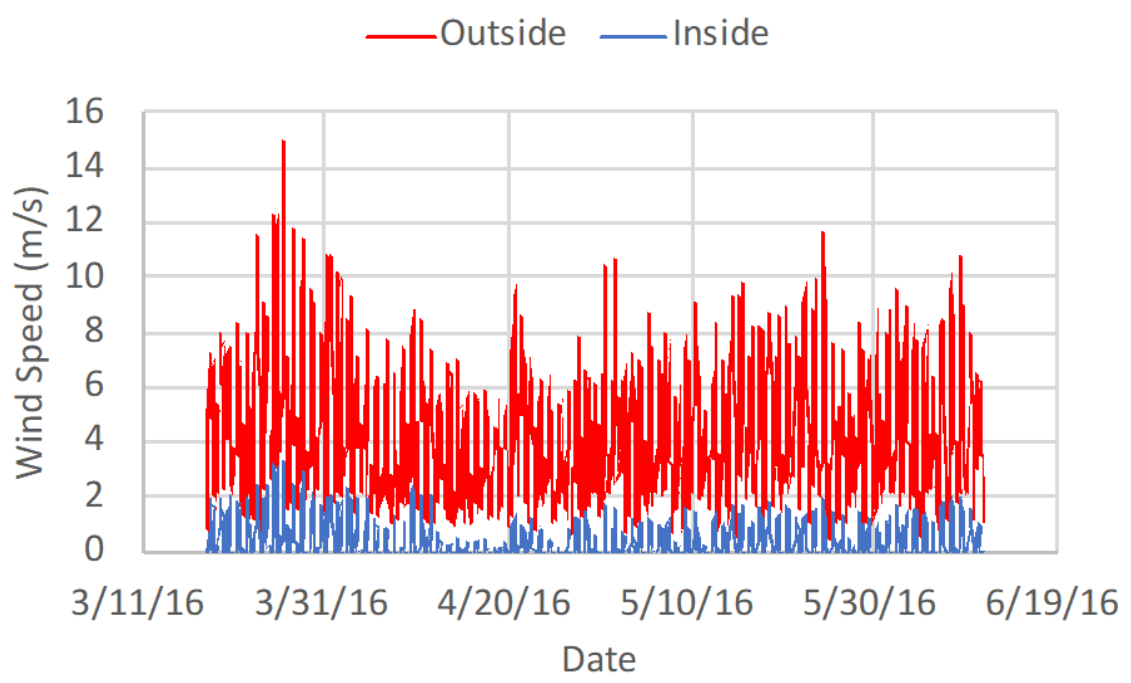

Figure 9. Comparison of wind speed inside and outside of the shade house between March 18 and June 19, 2016.

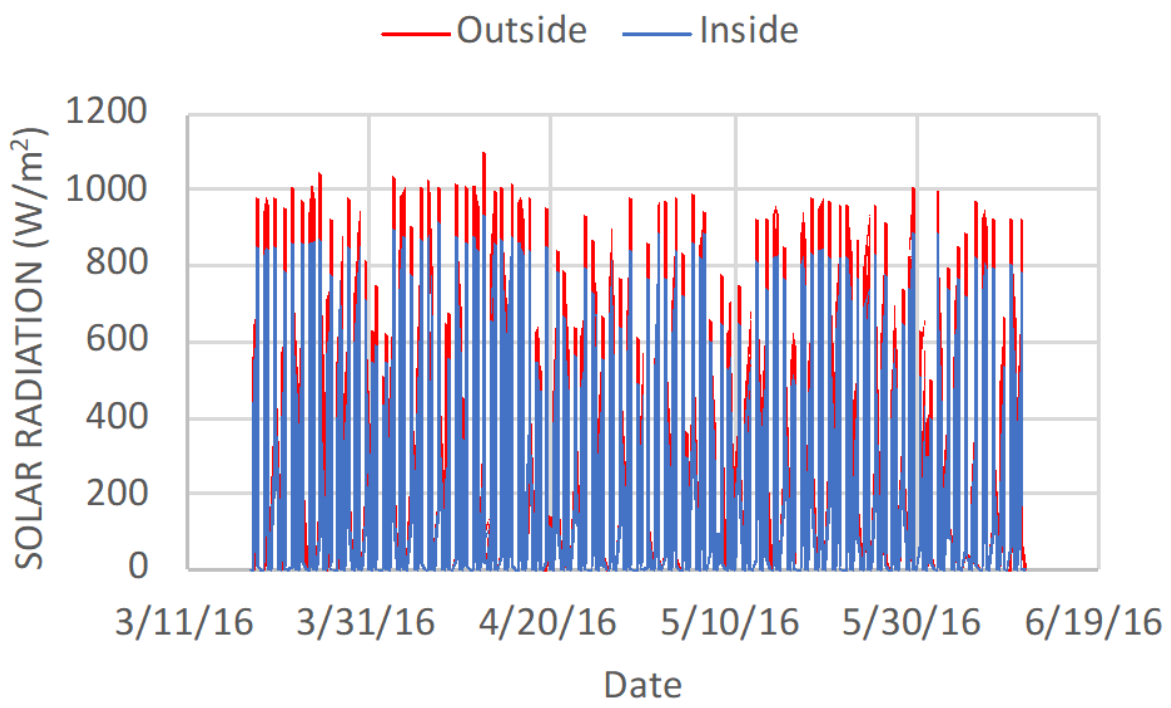

Figure 10. Comparison of solar radiation inside and outside of the shade house between March 18 and June 19, 2016. 


\section{Conclusion}

Shade houses reduce the main pests of the pepper, Capsicum annuum, and promotes higher yields. Therefore, we consider shade houses an alternative method for pepper production to successfully manage its two main pests, Anthonomus eugenii and Helicoverpa zea. The yield of watermelon was not impacted by shade houses. In the case of cabbage, shade houses did not promote adequate cabbage head development. Planting cabbage outside shade houses remains an alternative. Differences in average air temperature, relative humidity, wind speed, and solar radiation between shade houses and the open field were observed. Average measured differences inside and outside the shade house were $0.75^{\circ} \mathrm{C}, 1.8 \%,-1.44 \mathrm{~m} / \mathrm{s}$ and $-49.5 \mathrm{WATT} / \mathrm{m}^{2}$ for air temperature, relative humidity, wind speed, and solar radiation, respectively.

\section{Acknowledgments}

This work was supported by the National Institute of Food and Agriculture (NIFA) Hatch Program of the United States Department of Agriculture and by the Agricultural Experiment Station of the University of Puerto Rico. Three anonymous reviewers helped us with improve this manuscript with their extensive and constructive comments.

\section{Literature Cited}

Abrams, R., L. Almodóvar, C. Cruz, L. Cruz Pérez, H. Irizarry, R. Irizarry, G. Jackson, J. Jordán Moleero, F. Juliá, A. Lloréns, J. H. López, G. Mangual, P. L. Meléndez, A. V. Méndez, A. Morales, M. E. Pérez Escolar, I. Reyes Soto, M. Rico Ballester, J. Roldán, J. Román Toro, A. Serrano, C. Sierra, G. L. Spain, J. Toro (Científicos de la Estación Experimental Agrícola y la Facultad), and M. González Flores (Servicio de Extensión Agrícola). 1976. Conjunto Tecnológico para la Producción de Hortalizas. Universidad de Puerto Rico, Recinto Universitario de Mayagüez. Colegio de Ciencias Agrícolas. Río Piedras, Puerto Rico. Boletín 102. $95 \mathrm{pp}$.

Abreu, E. and C. Cruz. 1997. Enemigos naturales de Plutella xylostella (L.), (Lepidoptera: Plutellidae) en Puerto Rico. Journal of Agriculture of the University of Puerto Rico 81(1-2):83-85.

Albright, M. 2010. ATMOS. Puerto Rico Observed Climate Normals (1981-2010). University of Puerto Rico Climate Office. URL https://atmos.uw.edu/marka/normals/pr.normals.2010.html.

Allen R. G., L. S. Pereira, D. Raes and M. Smith. 1998. Crop Evapotranspiration. Guidelines for Computing Crop Water Requirements. FAO Irrigation and Drainage Paper 56. FAO - Food and Agriculture Organization of the United Nations Rome. 300 D05109.

Anonymous. 2014. Census of Agriculture Puerto Rico, 2007-2012, Puerto Rico. 2011. Net house vegetable production. Pest Management successes and challenges. Journal of the National Association of County Agricultural Agents (NACAA) 4(1). https://www.nacaa.com/journal/index.php?jid=87

[NACAA is the abbreviation for the US National Association of County Agricultural Agents.]

Baker C., S. Webb, and S. Adkins. 2008. Squash Vein Yellowing Virus, causal agent of watermelon vine decline in Florida. Plant Pathology Circular. No. 407. Florida Department of Agriculture and Consumer services. Division of Plant Industry. 4 pp. https://www.fdacs.gov/content/download/11413/file/pp407.pdf

Bita, C. and T. Gerats. 2013. Plant tolerance to high temperature in a changing environment: scientific fundamentals and production of heat stress-tolerant crops. Frontiers in Plant Science 4:273. https://doi.org/10.3389/fpls.2013.00273

Capinera, J. 2018. Diamondback Month, Plutella xylostella (Linnaeus) (Insecta: Lepidoptera: Plutellidae). University of Florida. EENY 119. 6 pp. https://edis.ifas.ufl.edu/in276

Crespo M. 2010. Proposal and report to need establish studies in vegetable with Shades House. Land Authority Report. San Juan, Puerto Rico. 9 pp. 
Di Rienzo, J. A., F. Casanoves, M. Balzarini, L. Gonzalez, M. Tablada, and C. W. Robledo. 2018. InfoStat. Software Estadistico. Universidad Nacional de Córdoba. Córdoba, Argentina. https://www.infostat.com.ar/?lang=en

Goyal, M. R. and E. A. González. 1989. Datos Climatológicos de las Subestaciones Experimentales Agrícolas de Puerto Rico. Publicación 88-70. Proyecto C-4-11. Estación Experimental Agrícola, Universidad de Puerto Rico. Mayagüez, Puerto Rico. 87 pp.

Harcourt, D. G. 1957. Biology of the diamondblack moth Plutella maculipennis in Eastern Ontario II. Life-history, behavior and host relations Canadian Entomologist 89:554-564. https://doi.org/10.4039/Ent89554-12

Harmsen, E. W., P. Tosado, and J. Mecikalski. 2014. Calibration of selected pyrometers and satellitederived solar radiation in Puerto Rico. International Journal of Renewable Energy and Technology 5(1):43-54. https://doi.org/10.1504/IJRET.2014.059660

Ilic, Z. S., L. Milenkovic, L. Sunic, S. Barac, J. Mastilovic, Ž. Keveresan, and E. Fallik, 2017. Effect of shading by coloured nets on yield and fruit quality of sweet pepper. ZemdirbysteAgriculture 104(1):53-61. https://doi.org/10.13080/z-a.2017.104.008

López-Marín, J., A. González, and A. Gálvez. 2011. Effect of shade on quality of greenhouse peppers. pp. 895-900. In, Proceedings of the International Symposium on High Technology for Greenhouse Systems: GreenSys2009. Québec City, Canada. June 14-19, 2009. Co-conveners: M. Dorais and A. Gosselin. M. Dorais (Editor). International Society for Horticultural Science. Leuven, Belgium. Two volumes. 1,358 pp. https://doi.org/10.17660/ActaHortic.2011.893.99, http://www.actahort.org/books/893/

Majumdar, A. and M. Powell.2011. Net house vegetable production: Pest management successes and challenges. Journal of the NACAA 4(1). https://www.nacaa.com/journal/index.php?jid=87 [NACAA is the abbreviation for the US National Association of County Agricultural Agents.]

Martínez, S. and G. Fornaris. 2005. Conjunto Tecnológico para la Producción de Pimiento Tipo Cubanelle y Campana. Universidad de Puerto Rico, Recinto Universitario de Mayagüez. Colegio de Ciencias Agrícolas. Estación Experimental Agrícola. Rio Piedras, Puerto Rico. Boletín 164. 96 pp.

Martínez, S. and G. Fornaris. 2015. Conjunto Tecnológico para la Producción de Sandía. Universidad de Puerto Rico, Recinto Universitario de Mayagüez. Colegio de Ciencias Agrícolas. Estación Experimental Agrícola. Rio Piedras, Puerto Rico. Boletín 159. 95 pp.

Pantojas A. 2002. Prácticas para el manejo integrado del picudo del pimiento en Puerto Rico. pp. 1819. In, Abreu, E. and A. Armstrong 2002. Daño Causado por el Picudo del Pimiento. Boletín 301. Estación Experimental Agrícola. Universidad de Puerto Rico. 66 pp.

Roberts, P. D., P. A. Stansly, S. T. Adkins, C. S. Kousik, and B. D. Bruton. 2007. Management of whitefly populations for control of watermelon vine decline in Florida. Phytopathology 97:S182.

Santoyo Juárez, J. A. and C. O. Martínez Alvarado. 2012. Tecnología de producción de chile habanero en casa sombra en el sur de Sinaloa. Fundación Produce Sinaloa. A. C. Gobierno del Estado de Sinaloa, México. 23 pp. file://C:/Users/Jorge/Downloads/Tecnolog\%C3\%ADa $\% 20 \mathrm{de} \% 20$ producci $\% \mathrm{C} 3 \% \mathrm{~B} 3 \mathrm{n} \% 20 \mathrm{de} \%$ 20chile\%20habanero\%20en\%20casa\%20sombra\%20en\%20el\%20sur\%20de\%20Sinaloa.pdf.

Segarra-Carmona, A. E. and A. Pantoja. 1988. Sequential sampling plan, yield loss components and economic thresholds for the pepper weevil, Anthonomus eugenii Cano (Coleoptera: Curculionidae). Journal of Agriculture University of Puerto Rico 72:375-385.

Sun, Y. P., Z. P. Zhang, and L. J. Wang. 2009. Promotion of 5-aminolevulinic acid treatment on leaf photosynthesis is related with increase of antioxidant enzyme activity in watermelon seedlings grown under shade condition. Photosynthetica 47(3):347. https://doi.org/10.1007/s11099-009$\underline{0055-\mathrm{y}}$

Talekar, N. S., F. C. Su, and M. Y. Lin. 2003. How to grow safer leafy vegetables in nethouses and net tunnels. International Cooperator's Guide. Asian Vegetable Research and Development Center (AVRDC). Publication\#03-558. 6pp. http://203.64.245.61/web crops/technologies/nethouse guide.pdf

Wegley, H. L., D. R. Eliott, W. R. Barchet, and R. L. George. 1981. Wind Energy Resource Atlas: Volume 12 - Puerto Rico and the U.S. Virgin Islands. Prepared for Pacific Northwest Laboratory (Richland, Washington, USA). Under Contract DE-AV06-76RLO 1830. Pacific Northwest 
Laboratory. Operated for the U.S. Department of Energy by Battelle Memorial Institute. PNL3195 WERA-12 UC-60. 77 pp. https://www.osti.gov/servlets/purl/67811414WK1b0/Windenergyresourceatlas.Volume12.PuertoRicoandUSVirginIslands.pdf

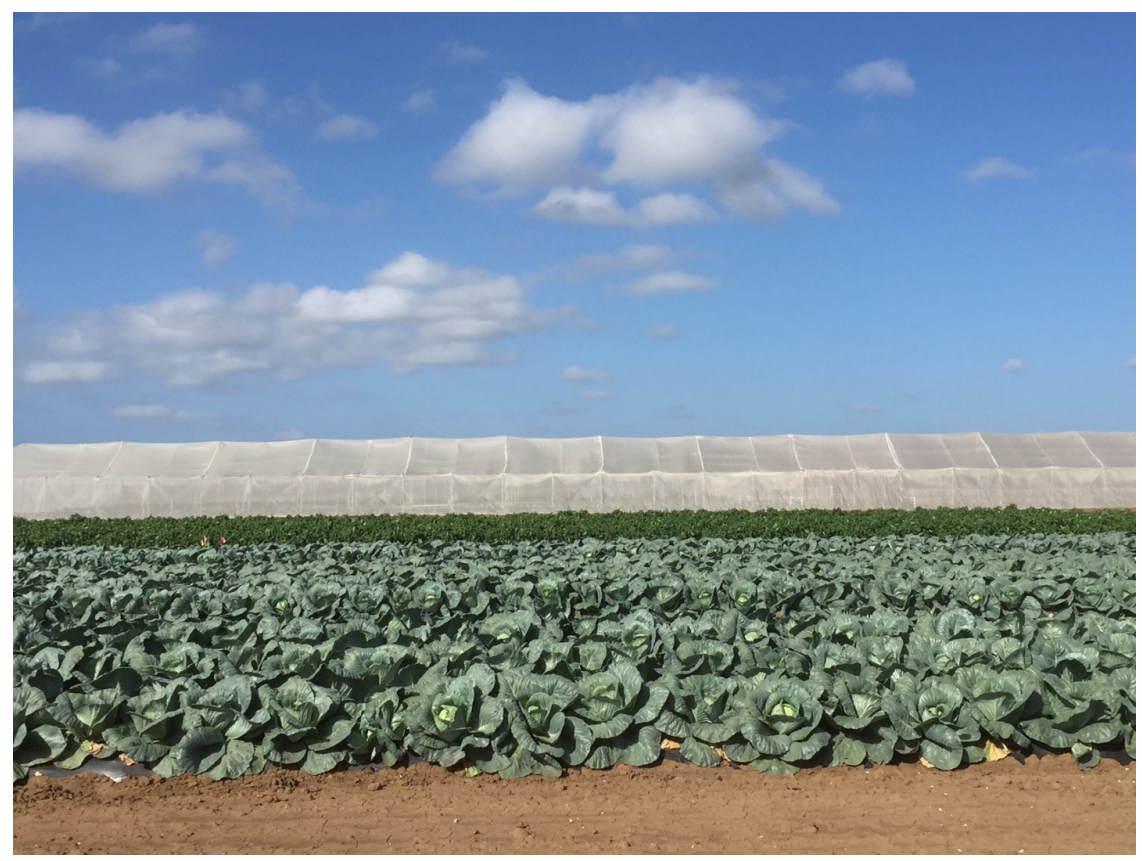

Figure 11. Almost complete view of a shade house. Cabbage plants (greyish green) in the foreground; pepper plants (dark green) between the shade house and the cabbage plants. 